Najvar, P., Slavík, J., Vlčková, K., Kubiatko, M., Pavlas, T., \& Janko, T. (2011). Kurikulární reforma na gymnáziích: dotazníkové šetření. In T. Janík, P. Knecht, \& S. Šebestová (Eds.), Smíšený design v pedagogickém výzkumu: Sborník přispěvkỉ z 19. výroční konference České asociace pedagogického výzkumu (s. 17-23). Brno: Masarykova univerzita.

Dostupné z: http://www.ped.muni.cz/capv2011/sbornikprispevku/najvaretal.pdf

doi: $10.5817 /$ PdF.P210-CAPV-2012-40

\title{
Kurikulární reforma na gymnáziích: dotazníkové šetření
}

\section{Curricular reform at grammar schools: questionnaire survey}

\author{
Petr Najvar, Jan Slavík, Kateřina Vlčková, Milan Kubiatko, \\ Tomáš Pavlas, Tomáš Janko
}

\begin{abstract}
Anotace: Příspěvek představuje druhou fázi výzkumu kurikulární reformy na gymnáziích. Jejím cílem bylo vyhodnotit aktuální fázi kurikulární reformy na gymnáziích, která spočívá v zahájení výuky podle školních vzdělávacích programů. Pozornost výzkumu byla soustředěna do tř́ oblastí: akceptace kurikulární reformy, učitelovo pojetí kurikula, využití a účinky kurikula. Výzkumný vzorek sestával z 1098 respondentů z 58 škol.
\end{abstract}

Klíčová slova: kurikulární reforma, gymnázium, výzkum

\begin{abstract}
The text presents the second phase of a research that focused on the curricular reform that was being implemented to upper-secondary comprehensive schools. The aim of this phase was to analyse the phase of the reform that consisted in implementing school education programmes into teaching practice. The research focused on three areas: acceptance of the curricular reform, teachers' beliefs about curriculum and effects of curriculum. The sample consisted of 1098 respondents from 58 schools.
\end{abstract}

Keywords: curricular reform, upper-secondary school, research

\section{1 Úvodem}

Ve výzkumu kurikulárních reforem lze vymezit celou řadu předmětných oblastí. Vedle sociálních a politických souvislostí reforem se lze zaměřit na konceptualizace a ověřování účelu a cílů kurikulárních reforem, na deficitní analýzy (např. nulové kurikulum - chybějící vzdělávací obsahy aj.), na kritiku kurikulárních reforem ukotvenou v levicových politických teoriích či na tvorbu, funkce, implementaci a revizi kurikulárních dokumentů. Lze se rovněž zaměřit na dopad reforem na jednotlivé aktéry vzdělávacího procesu (evaluace reforem) či provádět mezinárodní srovnávací analýzy kurikulárních reforem. Prezentované šetření bylo zaměřeno především na akceptaci kurikulární reformy, na učitelovo pojetí kurikula a na využití a účinky kurikula.

Akceptaci (přijímání) vymezujeme jako pozitivní postoj vi̊či zaváděné změně. V případě negativního postoje vůči zaváděné změně hovoříme o neakceptaci (nepřijímání). Předmětem akceptace je zde kurikulární reforma, resp. nový systém kurikulárních dokumentů (RVP/ŠVP) včetně způsobu jeho zavádění. Kurikulární reforma byla operacionalizována výčtem výroků poukazujících $\mathrm{k}$ př́nosům reformy na straně jedné a $\mathrm{k}$ jejím problémům na straně druhé. Tyto výroky vyjadřovaly určitou souhrnnou představu o tom, co reforma $\mathrm{z}$ pohledu gymnázií obnáší. V souvislosti se zkoumáním akceptace se vyhodnocoval vliv dalších proměnných (pohlaví, délka praxe, aprobace, spokojenost se školstvím, obeznámenost s reformou, podpora reformě apod.). 
Koncepce našeho výzkumu je soustředěna na propojování teorie s praxí, tzn. na zkoumání takových proměnných, které přiléhají $\mathrm{k}$ reálným problémům učitelů a škol. Patří $\mathrm{k}$ nim také učitelovo pojetí kurikula, tj. proměnná postihující způsob učitelova chápání a posuzování kurikula, který se promítá do jeho jednání ve výuce i mimo ni. Pojetí kurikula slouží učiteli jako rámec pro uvažování, argumentaci a rozhodování o tom, jak s kurikulem zacházet a jaké postoje k němu zaujímat. Rozhoduje o tom, jakým způsobem a do jaké míry učitel přijímá (akceptuje), nebo naopak odmítá např. státní kurikulární programy, které k němu přicházejí z vnějšku, ze strany řídících a společenských institucí.

Na fungování kurikulárních dokumentů usuzujeme na základě toho, k jakým účelům jsou ve školách tyto dokumenty využívány a co tyto dokumenty ve školách způsobují. Souhrn působení kurikulárních dokumentů zde označujeme pojmem účinky kurikula. $Z$ uvedeného je patrné, že účely využití a účinky kurikula jsou nahlíženy v těsném vztahu. Zatímco využití kurikula se vztahuje $\mathrm{k}$ účelům, $\mathrm{s}$ nimiž jsou kurikulární dokumenty využívány, účinky kurikula odkazují ke konkrétním změnám, jež jsou jimi způsobovány. Účely využití (resp. funkce) a účinky kurikula bývají zkoumány diferencovaně $v$ různých rovinách školského systému - např. (a) v rovině školství (makrorovina), (b) v rovině školy (mezorovina) a (c) v rovině školní třídy, resp. výuky (mikrorovina) apod. V našem přístupu jsou účely využití a účinky kurikula chápány jako pomyslný koncový článek působení řetězce proměnných. $\mathrm{K}$ jejich rozkrytí směřujeme prostřednictvím zkoumání toho, jak jsou kurikulární dokumenty ve školách akceptovány, jak jsou pojímány řediteli a učiteli a $\mathrm{k}$ jakým účelům jsou využívány. Všechny uvedené proměnné zkoumáme z perspektivy škol, přesněji řečeno ředitelů a učitelů jako koncových uživatelů kurikulárních dokumentů.

\section{Metodický postup}

Tvorba dotazníku a jeho pilotáž probíhala v lednu 2010, sběr dat pro hlavní šetření v květnu a červnu 2010, analýzy v červenci-záŕí 2010 a výzkumná zpráva byla zpracována a vydána tiskem v období říjen-prosinec 2010. Dotazníkové šetření bylo realizováno na souboru 1098 respondentů (758 žen, 340 mužů), z 58 gymnázií (46 nepilotních a 12 pilotních). Výsledky jsou zpracovány formou odborné knihy s názvem Kurikulární reforma na gymnáziích: výsledky dotazníkového šetření (Janík et al., 2010b), která obsahuje: širší kontext kurikulární reformy obecně v ČR a specificky v oblasti gymnaziálního vzdělávání; metodický postup dotazníkového šetření; výsledky vztahující se k následujícím oblastem: akceptace kurikulární reformy, učitelovo pojetí kurikula, využití a účinky kurikulárních dokumentů; diskusi výzkumných zjištění a rozvahu nad aktuální situací kurikulární reformy na gymnáziích (více viz Janík et al., 2010).

\section{Vybrané výsledky a diskuse}

\subsection{Akceptace kurikulární reformy}

Výsledky naznačují, že reforma jako taková není na gymnáziích většinově akceptována skupina akceptujících je relativně málo početná (asi $14 \%$ respondentů), skupina neakceptujících je početnější (asi $30 \%$ respondentů), největší je skupina respondentů, kteří zaujímají vůči reformě ambivalentní vztah ( $55 \%$ respondentů).

Tyto skupiny byly definovány dle míry souhlasu respondentů s výroky vztahujícími se $\mathrm{k}$ př́nosům reformy na straně jedné a $\mathrm{k}$ jejím problémům na straně druhé. Skupina akceptujících tak zahrnovala respondenty, kteří vidí především př́nosy reformy a neobávají se tolik jejích problémů, a skupina neakceptujících zahrnovala respondenty, pro něž nejsou 
přínosy reformy až tak podstatné, naopak její problémy berou jako závažné. Velikost skupiny ambivalentních (nevyhraněných) respondentů, kteří vítají přínosy a nepodceňují problémy, je dokladem převažujícího konstruktivně kritického postoje vůči reformě. Tyto výsledky vnímáme jako signál o tom, že gymnázia mají potřebu v duchu své tradice pečlivě přezkoumávat vše, co jim je předkládáno k zavedení.

Na pilotních gymnáziích je akceptace reformy vyšší než na nepilotních. Vedení škol akceptuje reformu více než řadoví učitelé. Ženy akceptují reformu více než muži. Délka praxe nemá na akceptaci reformy vliv. Aprobace respondenta nemá na akceptaci reformy vliv. Respondenti, kteří nejsou s reformou př́liš obeznámeni, mají vyšší tendenci ji odmítat. Akceptace reformy je do jisté míry výsledkem informovaného rozhodování. Akceptaci reformy z hlediska pozice, kterou respondent zastává ve škole, ukazuje obrázek 1.

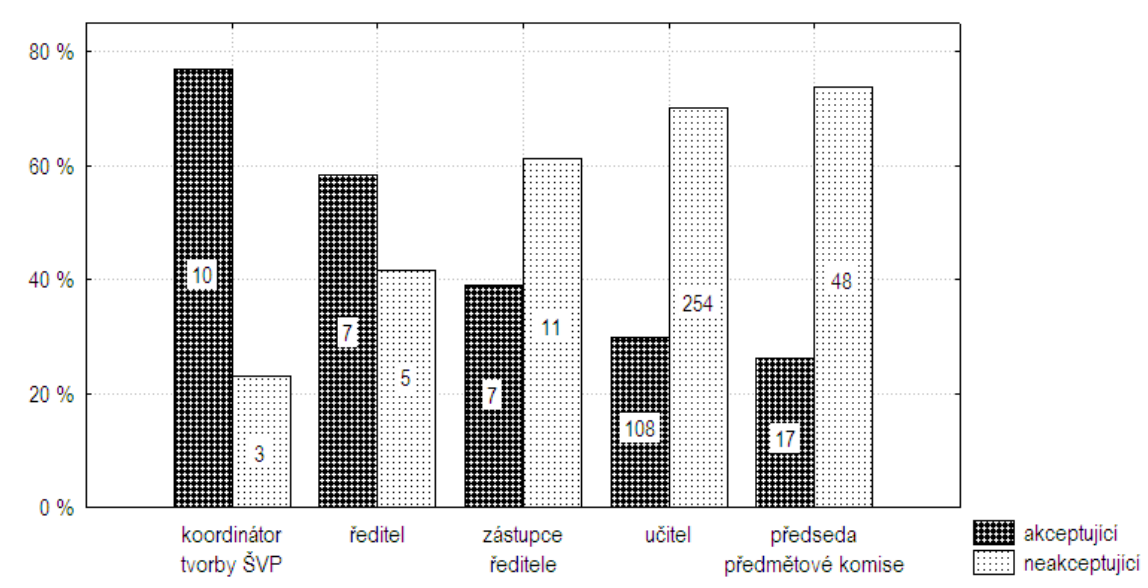

Obrázek 1. Akceptace reformy podle pozice na škole

Většinové názory učitelů jsou mnohem kritičtější, než jaké jsme zaznamenávali v rozhovorech s koordinátory na pilotních a partnerských školách. Toto zjištění není překvapivé, nebot' česká situace $\mathrm{v}$ tomto ohledu není jedinečná $\mathrm{v}$ porovnání $\mathrm{s}$ ostatními zeměmi na západ od našich hranic. Výzkumy provedené v Německu či v Rakousku přinášejí obdobné výsledky. Řadoví učitelé se k tématu reforem vyjadřovali obdobným jazykem a $\mathrm{s}$ tendencí k invektivám směrem $\mathrm{k}$ tvůrcům státního kurikula, jako naši respondenti.

\subsection{Obeznámenost s kurikulární reformou a kurikulárními dokumenty}

Výzkum dokládá relativně vysokou míru obeznámenosti s ŠVP a s částí RVP týkající se předmětů respondentovy aprobace. Toto zjištění může být zatíženo efektem sociální žádoucnosti. Obeznámenost má vliv na akceptaci reformy - ukázalo se, že respondenti, kteří nejsou s reformou prŕliš obeznámeni, mají vyšší tendenci ji odmítat. Jinak řečeno, akceptace (přijímání) reformy je do jisté míry výsledkem informovaného rozhodování.

Relativně nejméně, avšak v celkovém pohledu průměrně jsou učitelé obeznámeni s částí RVP týkající se ostatních předmětů (tj. předmětů mimo respondentovu aprobaci). Toto zjištění se jeví jako důležité s ohledem na realizaci mezipředmětových vztahů. Přestože je obeznámenost $\mathrm{s}$ částí RVP týkající se ostatních předmětů nejnižší ze všech sledovaných položek, domníváme se, že její hodnota je poměrně vysoká. Jedná se totiž o druh obeznámenosti, který nebyl v době před reformou do té míry požadován. 


\subsection{Podpora reformy a podpora vyjadřovaná reformě}

Podporu reformy považují respondenti za velmi důležitou. Výsledky výzkumu poukazují na určitý rozpor mezi tím, jak respondenti vnímají důležitost podpory, a tím, jak hodnotí podporu, která jim byla poskytnuta. Podpora v oblasti finanční, materiální, informační a metodické, kterou respondenti považují za velmi důležitou, se jim nedostává v míře, jakou by si představovali (obrázek 2). Nejvyšší míra důležitosti byla vnímána u podpory materiální, jen o málo nižší u podpory finanční. Respondenti, kteří reformu akceptují, uvádí vyšší důležitost informační a metodické podpory; neliší se v pohledu na důležitost finanční a materiální podpory. Ukazuje se pozitivní souvislost podpory reformě ze strany respondenta s hodnocením důležitosti podpory školy při zavádění reformy.

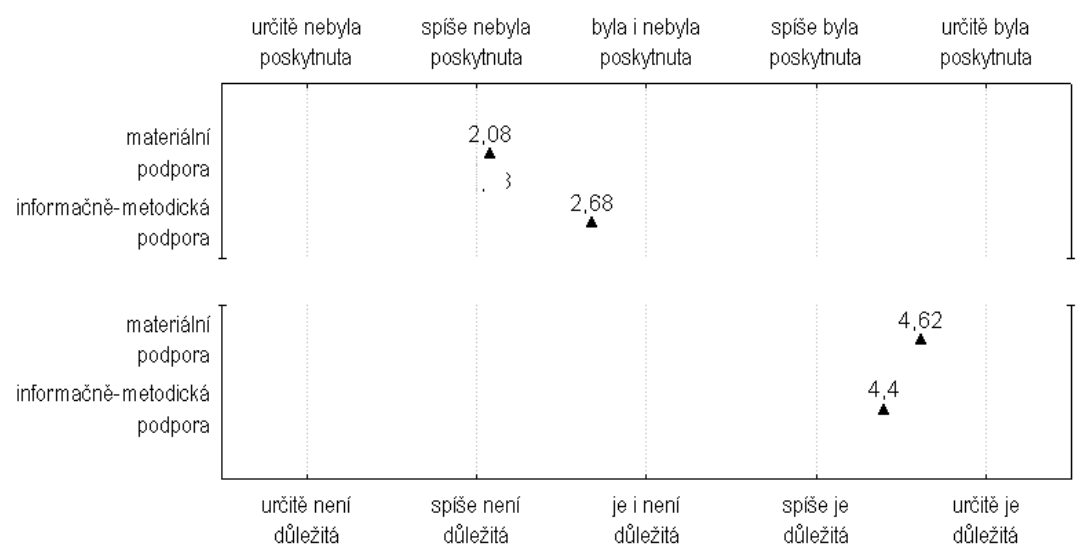

Obrázek 2. Porovnání důležitosti podpory a poskytnuté podpory (průměry)

Profil respondentů podporujících reformu ve vyšší míře (61-100 \%) se liší od profilu respondentů reformu podporujících v nižší míře (0-40\%). Ve vyšší míře má tendenci podporovat reformu vedení školy než učitelé. Ve vyšší míre reformu podporují respondenti, kteří ji zároveň akceptují.

\subsection{Učitelovo pojetí kurikula}

Respondenty lze podle pojetí kurikula a př́stupu k RVP či ŠVP rozdělit do tř́ typů: 1) zaměření na žáka (paidotropní), 2) zaměření na učivo (logotropní), 3) zaměření na systém (vstřícní k ŠVP, RVP). Tyto tři typy se vyznačují odlišnými názory na některé důležité stránky reformy. Nejrozsáhlejší skupina respondentů (přes $70 \%$ ) odpovídá typu ,zaměření na žáka“, přičemž jejím názorům je blízká i skupina typově nezařazených (15\%). Vůči reformě jsou tito respondenti názorově nevyhranění - s něčím souhlasí více, s něčím méně. Další nejčetnější skupina (10\%) odpovídá typu „zaměření na učivo“. Respondenti z této skupiny jsou k reformě nejkritičtější, tzn. nejsilněji vyjadřují obavy z poklesu úrovně žákovských znalosti, nejvíce se obávají důsledků reformy a nejvýrazněji upřednostňuji tradiční kurikulum před reformním. Respondenti typu „zaměření na systém“ jsou k reformě nejvstřícnější. Zpravidla považují reformu za naplnění jejich vlastního dosavadního př́stupu k výuce. Jsou však početně nejmenší skupinou - méně než $3 \%$. Všichni respondenti bez ohledu na jejich typové zařazení se relativně nejvíce obávají poklesu výkonu žáků (poklesu znalostí) jako důsledku reformy.

Př́iklon většiny respondentů k zaměření na žáka lze interpretovat jako projev humanistického a na žáka orientovaného př́stupu ke vzdělávání, který má v současné době u nás i ve světě 
značnou autoritu. Jde ovšem o vyjádřený názor, který může i nemusí v praxi odpovídat skutečnému stylu vyučování. Relativně nejkritičtější je pozice respondentů zaměřených na učivo. To lze při interpretaci propojit $\mathrm{s}$ obecněji vyjadřovanou obavou, že reforma povede k poklesu výkonu (znalostí) žákủ. Souvisí to zřejmě i s většinovým míněním, že reforma se týká hlavně metod a forem výuky, nikoliv tolik obsahu a cílů (viz níže). Respondenti zřejmě zužují reformu na posun důrazu od nároků na znalosti žáků $\mathrm{k}$ nárokům na motivující metody vyučování a usuzují z toho, že na základě reformy klesá zřetel k obsahu - učivu. Souhlas s reformou je často podmíněný tím, že pro respondenty představuje potvrzení jejich dosavadního směřování, at' již je tento jejich dojem zcela oprávněný, anebo vyplývá z více či méně zkresleného vnímání reformy. Obdobné zahraniční výzkumy ukazují, že zdrženlivost učitelů ke kurikulární reformě i rozrůzněnost jejich názorů na ni nejsou příznačné pouze pro aktuální českou kurikulární reformu.

\subsection{Kurikulární činnosti}

V jedné z dotazníkových baterií měli respondenti za úkol posoudit smysluplnost, obtížnost a problematičnost vybraných činností př́źznačných pro reformu. Celkový výsledek je příznačný malým rozptylem názorů. Většina respondentů pokládá sledované reformní aktivity za vysoce problematické a vysoce pracné, ale často je hodnotí jako vysoce smysluplné. Ředitelé škol nebo koordinátoři ŠVP častěji než řadoví učitelé pokládají některé reformní aktivity za smysluplné. Většina respondentů si kurikulární reformu spojuje se změnami v oblasti forem a metod výuky, méně se změnami v oblasti cílů nebo obsahu. V kvalitativní části dotazníku respondenti často uvádějí, že pro ně je reforma spojena s formalizmem nebo zvýšenými nároky na administrativu. Vyšší obeznámenost i vyšší souhlas s reformou prokazují a) učitelé pilotních škol oproti učitelům běžných škol, b) ředitelé a koordinátoři ŠVP většiny škol oproti řadovým učitelům těchto škol. Souhlas s reformními aktivitami častěji vyjadřují ti respondenti, kteří $\mathrm{v}$ nich spatřují potvrzení svého vlastního, již dříve uskutečňovaného př́istupu k výuce a ke kurikulu.

Výsledky naznačují, že respondenti mají vůči reformním aktivitám řadu obecných výhrad, nicméně při větší konkretizaci častěji přitakávají na jejich smysluplnost. Lze z toho usuzovat, že $\mathrm{v}$ těch případech, kdy jsou reformní aktivity srozumitelně a zdůvodněně zakotvené v praxi, setkávají se mezi učiteli s relativně největší ochotou je přijímat. S předchozím bodem souvisí zjištění, že ti respondenti, kteří měli možnost se s reformními aktivitami hlouběji seznámit a sami se jimi více zabývali (učitelé pilotních škol, ředitelé, koordinátoři), s nimi také nejvíce souhlasí. Míra souhlasu s reformou tedy odpovídá míře, v níž učitelé rozumějí nově zaváděnému kurikulu a dokážou s ním spojovat konkrétní prínosy pro svou práci.

\subsection{Funkce $\check{S} V P$ - ve škole a ve výuce}

ŠVP je respondenty považován za administrativní nástroj sloužící k ovlivňování chodu školy. Respondenti z pilotních gymnázií uvádí vyšší míru využívání ŠVP u všech zkoumaných účelů. Respondenti považují ŠVP především za určité východisko, z něhož plánují obsahy a cíle výuky. Vedení i učitelé ale shodně uvedli, že jim ŠVP nejvíce napomáhá při stanovení základního učiva pro žáky. Obrázek 3 ukazuje, jaké účely využití připisují respondenti ŠVP v rovině výuky.

Čeští učitelé připisují školnímu kurikulu obdobné funkce, jako učitelé v Německu nebo ve Švýcarsku. Respondentů si jsou vědomi nebezpečí formalismu při zavádění nových kurikulárních dokumentů. Formalismus kurikulární reformě hrozí zejména kvůli ztrátě vazby mezi ŠVP a reálnou prací učitele ve tř́dách. 


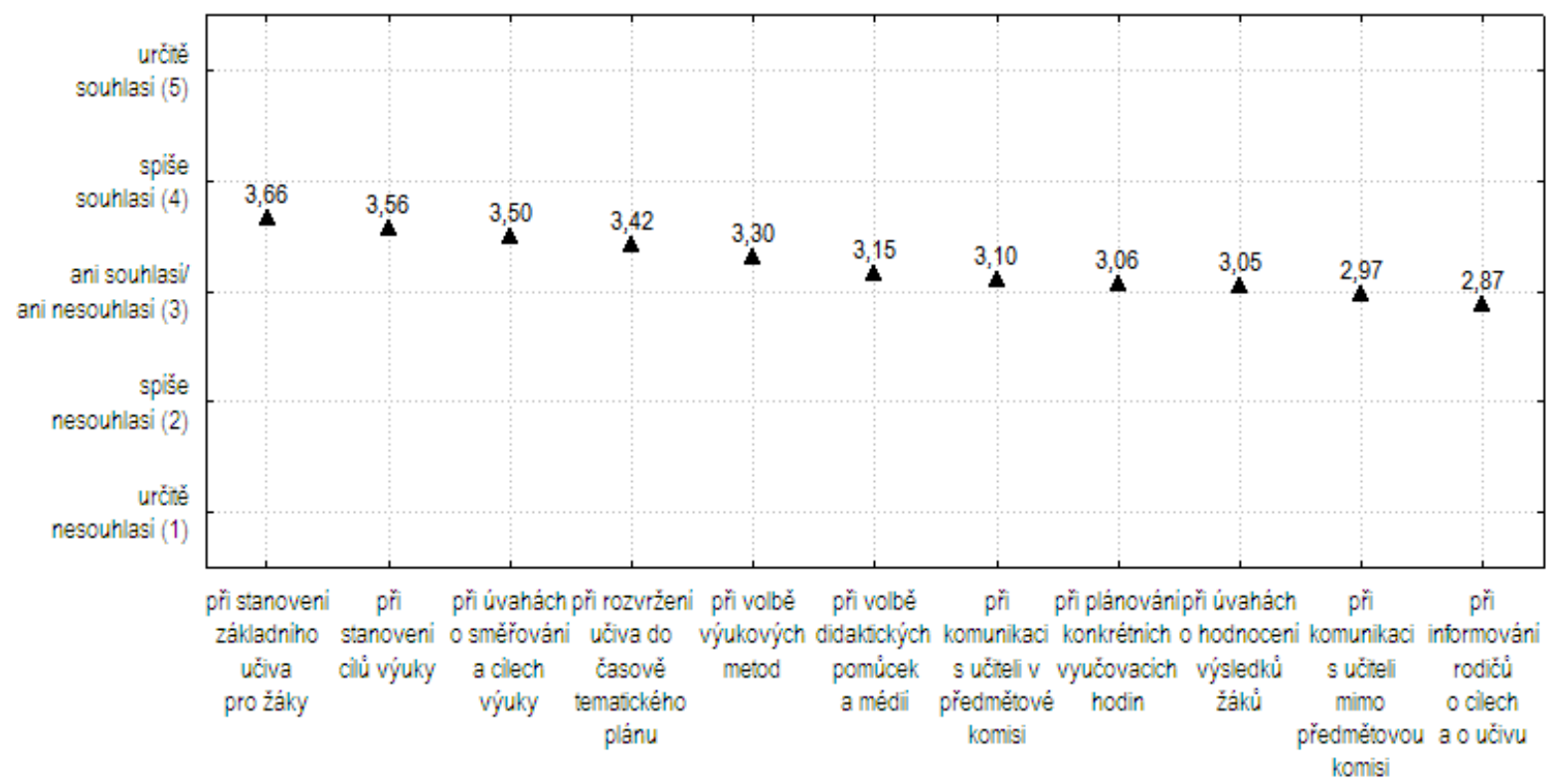

Obrázek 3. Účely využití ŠVP - rovina výuky (aritmetické průměry)

\subsection{Vliv ŠVP na postoje respondentů k edukační realitě}

Respondenti vnímají vliv ŠVP na své postoje k vybraným aspektům edukační reality jako nepatrný (hodnoty aritmetického průměru se pohybují u středu škály, tj. ani souhlasí, ani nesouhlasí). Respondenti uvádějí, že ŠVP nejvíce změnil jejich postoj k př́ípravě výuky. Členové vedení uvádějí, že ŠVP měl vliv préedevším na změnu jejich postojů $\mathrm{k}$ hodnocení výuky, zatímco učitelé uváděli, že ŠVP měl vliv na změnu jejich postoje $\mathrm{k}$ př́pravě výuky. Respondenti z pilotních gymnázií ve větši míře než respondenti z nepilotních připisovali ŠVP vliv na změnu postojů $\mathrm{k}$ vybraným aspektům edukační reality. Respondenti analyzovaných aprobací se statisticky významně neodlišovali v tom, jaký vliv na jejich postoje $\mathrm{k}$ edukační realitě ŠVP připisují.

\section{Závěrem}

Ukazuje se, že podíl na tvorbě ŠVP do jisté míry učitele aktivizoval, a to zejména učitele působící na pilotních gymnáziích. Ti tvořili ŠVP bez předchozích zkušeností, nicméně mohli čerpat metodickou podporu $\mathrm{v}$ rámci pilotáže. $\mathrm{V}$ konečném důsledku tak zřejmě měli více prostoru $\mathrm{k}$ diskusi ohledně tvorby ŠVP i k hlubšímu zamyšlení nad využitím, funkcemi a účinky kurikula. To mohlo jejich postoje k ŠVP pozitivně ovlivňovat. Účinky zavádění nových kurikulárních dokumentů se projevují v delším časovém horizontu, nebot' aktéri reforem potřebují pro postupné zavádění nových myšlenek a postupů čas a prostor. Zatím by bylo předčasné je hodnotit.

\section{Literatura}

Janík, T., Janko, T., Knecht, P., Kubiatko, M., Najvar, P., Pavlas, T., Slavík, J., Solnička, D., \& Vlčková, K. (2010). Kurikulární reforma na gymnáziích: výsledky dotazníkového šetření. Praha: Výzkumný ústav pedagogický v Praze. 


\section{Kontakt}

Mgr. Petr Najvar, Ph.D.

PaedDr. Milan Kubiatko, PhD.

Mgr. Tomáš Janko

doc. Mgr. et Mgr. Kateřina Vlčková, Ph.D.

Masarykova univerzita

Pedagogická fakulta, Institut výzkumu školního vzdělávání

Poříčí 7, 60300 Brno

e-mail:najvar@ped.muni.cz

doc. PaedDr. Jan Slavík, CSc.

Západočeská univerzita v Plzni

Pedagogická fakulta, Katedra výtvarné kultury

Univerzitní 22, 30614 Plzeň

e-mail: ars.gratia@tiscali.cz

Mgr. Tomáš Pavlas

Národní ústav pro vzdělávání

Senovážné náměstí 1588/4 , P. O. BOX 1422, 11121 Praha 1

e-mail:pavlas@vuppraha.cz

\section{Bibliografické údaje}

Najvar, P., Slavík, J., Vlčková, K., Kubiatko, M., Pavlas, T., \& Janko, T. (2011). Kurikulární reforma na gymnáziích: dotazníkové šetření. In T. Janík, P. Knecht, \& S. Šebestová (Eds.), Smíšený design v pedagogickém výzkumu: Sborník př́spěvků z 19. výročni konference České asociace pedagogického výzkumu (s. 17-23). Brno: Masarykova univerzita.

Dostupné z: http://www.ped.muni.cz/capv2011/sbornikprispevku/najvaretal.pdf

doi: 10.5817/PdF.P210-CAPV-2012-40 